\title{
Structural mechanisms of DREAM complex assembly and regulation
}

\author{
Keelan Z. Guiley, ${ }^{1}$ Tyler J. Liban, ${ }^{1}$ Jessica G. Felthousen, ${ }^{2,3}$ Parameshwaran Ramanan, ${ }^{1}$ \\ Larisa Litovchick, ${ }^{2,3}$ and Seth M. Rubin ${ }^{1}$ \\ ${ }^{1}$ Department of Chemistry and Biochemistry, University of California at Santa Cruz, Santa Cruz, California 95064, USA; \\ ${ }^{2}$ Division of Hematology, Oncology, and Palliative Care, ${ }^{3}$ Massey Cancer Center, Virginia Commonwealth University, \\ Richmond, Virginia 23298, USA
}

The DREAM complex represses cell cycle genes during quiescence through scaffolding MuvB proteins with E2F4/5 and the Rb tumor suppressor paralog p107 or p130. Upon cell cycle entry, MuvB dissociates from p107/p130 and recruits B-Myb and FoxM1 for up-regulating mitotic gene expression. To understand the biochemical mechanisms underpinning DREAM function and regulation, we investigated the structural basis for DREAM assembly. We identified a sequence in the MuvB component LIN52 that binds directly to the pocket domains of p107 and p130 when phosphorylated on the DYRK1A kinase site S28. A crystal structure of the LIN52-p107 complex reveals that LIN52 uses a suboptimal LxSxExL sequence together with the phosphate at nearby S28 to bind the LxCxE cleft of the pocket domain with high affinity. The structure explains the specificity for p107/p130 over Rb in the DREAM complex and how the complex is disrupted by viral oncoproteins. Based on insights from the structure, we addressed how DREAM is disassembled upon cell cycle entry. We found that p130 and B-Myb can both bind the core MuvB complex simultaneously but that cyclin-dependent kinase phosphorylation of p130 weakens its association. Together, our data inform a novel target interface for studying MuvB and p130 function and the design of inhibitors that prevent tumor escape in quiescence.

[Keywords: cyclin-dependent kinases; DREAM complex; MuvB; cell cycle; phosphorylation; retinoblastoma-like proteins p107 and p130]

Supplemental material is available for this article.

Received December 18, 2014; revised April 3, 2015.

Cell cycle exit is a critical process for differentiation and tumor prevention, and cancer cells often have lesions in pathways that control temporary (quiescence) or permanent (senescence) exit. Understanding fundamental mechanisms of cell cycle exit is critical for understanding development and ultimately designing therapeutic strategies that manipulate exit pathways for halting tumor proliferation. Quiescence has recently been shown to be dependent on the highly conserved protein complex known as DREAM (Litovchick et al. 2007, 2011; Sadasivam and DeCaprio 2013). Genetics experiments in model organisms reveal an essential role for DREAM components in differentiation, cell proliferation, and tumor suppression (Korenjak et al. 2004; Lewis et al. 2004; Harrison et al. 2006; Litovchick et al. 2007; van den Heuvel and Dyson 2008; Reichert et al. 2010). DREAM-deficient mice die shortly after birth with bone developmental defects that result from aberrant chondrocyte differentiation (Forristal et al. 2014). In human cell culture, DREAM is assembled upon serum starvation in an experimental state

Corresponding authors: srubin@ucsc.edu, llitovchick@vcu.edu Article published online ahead of print. Article and publication date are online at http://www.genesdev.org/cgi/doi/10.1101/gad.257568.114. of quiescence, and disruption of the DREAM complex drives cells back into the cell cycle despite environmental cues to arrest (Pilkinton et al. 2007; Schmit et al. 2007; Litovchick et al. 2011).

Chromatin immunoprecipitation (ChIP) has located DREAM proteins at a majority of E2F and cell cycle homology region (CHR) promoters in human cells, and gene expression analysis has implicated DREAM as a repressor of cell cycle genes (Litovchick et al. 2007; Schmit et al. 2007; Muller et al. 2012). The mechanism of how DREAM regulates transcription has not been elucidated, but it is clear that its central components scaffold a number of key cell cycle transcription factors, including E2F4/ 5, B-Myb, FoxM1, and the $\mathrm{Rb}$ tumor suppressor family paralogs p107 and p130 (Korenjak et al. 2004; Lewis et al. 2004; Litovchick et al. 2007; Schmit et al. 2007; Sadasivam et al. 2012). DREAM was originally isolated through biochemical purification in flies and worms,

C 2015 Guiley et al. This article is distributed exclusively by Cold Spring Harbor Laboratory Press for the first six months after the full-issue publication date (see http://genesdev.cshlp.org/site/misc/terms.xhtml). After six months, it is available under a Creative Commons License (Attribution-NonCommercial 4.0 International), as described at http:// creativecommons.org/licenses/by-nc/4.0/. 
and in each case, the complex contained multivulval class B protein homologs LIN9, LIN37, LIN52, LIN54, and RBAP48 (mammalian protein names), which together are called the MuvB subcomplex (Korenjak et al. 2004; Lewis et al. 2004; Harrison et al. 2006; van den Heuvel and Dyson 2008). The biochemical functions of these proteins are unknown, with the exception of RBAP48 and LIN54, which bind histones and DNA, respectively (van den Heuvel and Dyson 2008; Sadasivam and DeCaprio 2013).

In mammalian cells, MuvB associates with p130-E2F4/5 to form DREAM in $\mathrm{G}_{0}$ and early $\mathrm{G}_{1}$ and associates with $\mathrm{B}-\mathrm{Myb}$ during $\mathrm{S}$ phase to form the Myb-MuvB (MMB) complex (Pilkinton et al. 2007; Schmit et al. 2007; Litovchick et al. 2011; Sadasivam et al. 2012). While DREAM represses gene expression, MMB activates late cell cycle genes during $S$ phase and $G_{2}$ both with and without FoxM1 (Georlette et al. 2007; Litovchick et al. 2007; Pilkinton et al. 2007; Schmit et al. 2007; Wen et al. 2008; Sadasivam et al. 2012). MuvB thus has an intriguing role in unifying cell cycle-dependent gene expression; however, the mechanisms by which DREAM and MMB-FoxM1 are assembled and regulated to carry out their specific functions are not well understood. DREAM formation requires the phosphorylation of MuvB protein LIN52 at serine residue 28 (phosS28) by the DYRK1A kinase (Litovchick et al. 2011). "Delta DREAM" mice that lack p130 and carry a p107 mutant allele incapable of binding MuvB display a phenotype identical to that of p107/p130 doubleknockout mice, suggesting an intimate relationship between the pocket proteins and MuvB proteins during cell cycle arrest (Forristal et al. 2014). While there are some reports of MuvB binding Rb (Gagrica et al. 2004; Korenjak et al. 2004), other evidence indicates that the DREAM complex only assembles with either p107 or p130 (Litovchick et al. 2007; Pilkinton et al. 2007; Schmit et al. 2007; Forristal et al. 2014). p130 expression levels are high during quiescence, and p130 is an established biomarker at this stage of the cell cycle in which DREAM is a repressor of gene expression (Smith et al. 1996; Henley and Dick 2012). Loss of p130 results in up-regulated expression of p107 and subsequent recruitment of p107 to MuvB (Litovchick et al. 2007; Forristal et al. 2014). MuvB dissociation from pocket proteins coincides with cyclin-dependent kinase (Cdk) activity (Pilkinton et al. 2007), suggesting that Cdk phosphorylation of p107 and p130 may inhibit DREAM formation in cycling cells. Knowledge of the molecular architecture of the MuvB complex, how MuvB binds different transcription factors, and how these associations are manipulated throughout the cell cycle is important for understanding fundamental processes such as entry into quiescence and mitotic cell cycle control.

Here we describe the structural mechanisms of DREAM assembly following DYRK1A phosphorylation and DREAM inhibition by either oncogenic viral proteins or Cdk phosphorylation. We found that phosphorylated LIN52 binds the pocket domain of p107 or p130 using a short sequence that is a tunable variation of the canonical LxCxExL Rb-binding sequence. A crystal structure of a LIN52-p107 complex explains the requirement for phosphorylation, why the association is specific for p107/ p130 and not Rb, and how DREAM is inhibited by viral proteins. The structural observations lead us to uncover a novel model for cell cycle-dependent regulation of DREAM assembly in which Cdk phosphorylation of pocket proteins induces a conformation that is incompatible with LIN52 binding.

\section{Results \\ p107 and p130 directly associate with LIN52}

It has been shown previously that p107 and p130 coimmunoprecipitate with MuvB proteins if S28 in LIN52 is phosphorylated by DYRK1A (Litovchick et al. 2011). To determine whether LIN52 directly associates with p130, we performed a series of binding experiments with recombinant, purified proteins. We first purified full-length GST-LIN52-HIS and GST-p130, both expressed in Sf9 cells, and found coprecipitation using $\mathrm{Ni}^{2+}$ affinity resin (Fig. 1A). Electrospray mass spectrometry indicated that the LIN52 purified from Sf9 cells is phosphorylated (Supplemental Fig. 1A,B). Given the observation that the binding appears substoichiometric, we postulated that p130 is heterogeneously phosphorylated in Sf9 cells, as previously observed for Rb (Burke et al. 2010), and that phosphorylation weakens LIN52 association. We treated p130 with $\lambda$ phosphatase during purification and observed a band shift on a Phos-tag SDS-PAGE gel (Supplemental Fig. 1C). After treatment with and subsequent separation from phosphatase, the p130-LIN52 complex stability appears increased (Fig. 1A).

We next tested whether phosphorylation of S28 in LIN52 is necessary for its direct interaction with pocket proteins. p130 and p107 pocket domains were expressed and purified from Escherichia coli without post-translational modifications. These constructs $(\mathrm{p} 107 \Delta \mathrm{L}$ and p130 LL) each lack two internal loops and are similar to crystallized $\mathrm{Rb}$ constructs that maintain E2F and viral protein-binding activity (Lee et al. 1998; Balog et al. 2011). We also purified LIN52 constructs expressed in Sf9 cells containing the N-terminal domain (residues 13-45; LIN52 ${ }^{13-}$ ${ }^{45}$ ). We found that LIN52 $2^{13-45}$ is sufficient for direct association with the p130 and p107 pocket domains. An S28A mutation in LIN52 $2^{13-45}$ or $\lambda$ phosphatase treatment reduces binding to p130 and p107 (Fig. 1B,C), demonstrating the importance of S28 phosphorylation for formation of the complex.

The pocket domain contains two protein interaction interfaces: the LxCxE cleft and the E2F transactivation domain (E2F ${ }^{\mathrm{TD}}$ )-binding site (Lee et al. 1998, 2002; Xiao et al. 2003; Dick and Rubin 2013). The LxCxE cleft binds viral and endogenous proteins containing an $\operatorname{LxCxEx} \varphi$ sequence motif ( $\mathrm{x}$ is any amino acid, and $\varphi$ is a hydrophobic amino acid) (Jones et al. 1990; Lee et al. 1998; Singh et al. 2005). A p107 cleft mutant fails to assemble DREAM in vivo (Forristal et al. 2014) and we therefore hypothesized that LIN52 directly binds to the LxCxE cleft rather than the $\mathrm{E} \mathrm{F}^{\mathrm{TD}}$ site. In support of this hypothesis, a purified p107 pocket domain cleft mutant (I931A, N935A, and V939A) fails to bind LIN52 (Fig. 1D). 
A

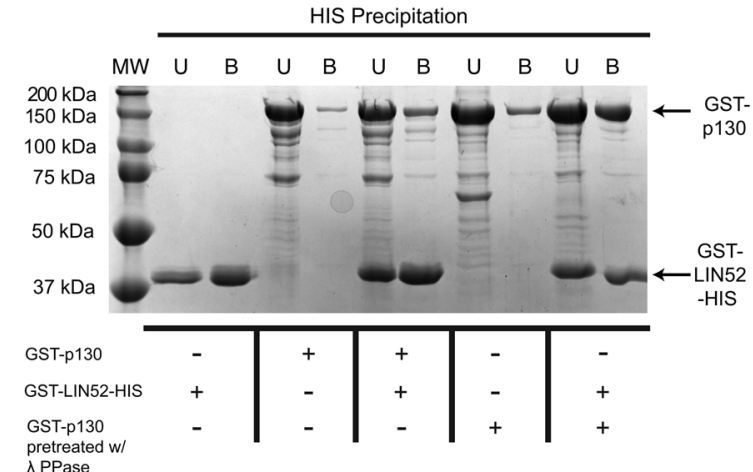

C

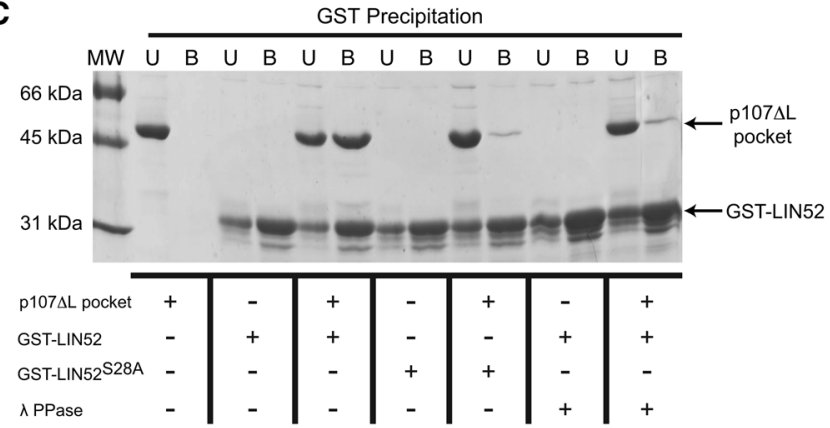

B

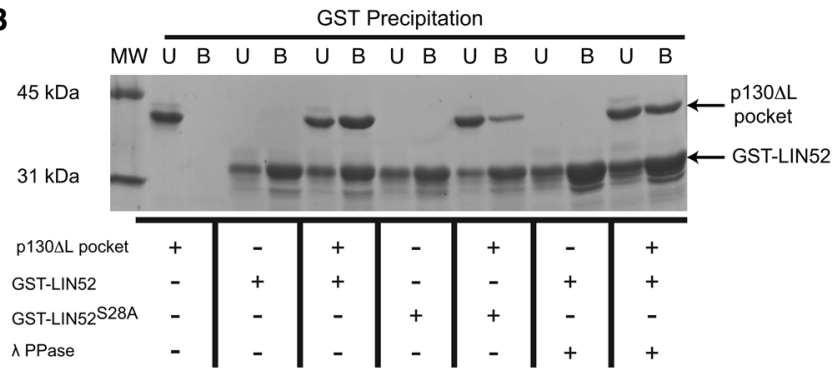

D

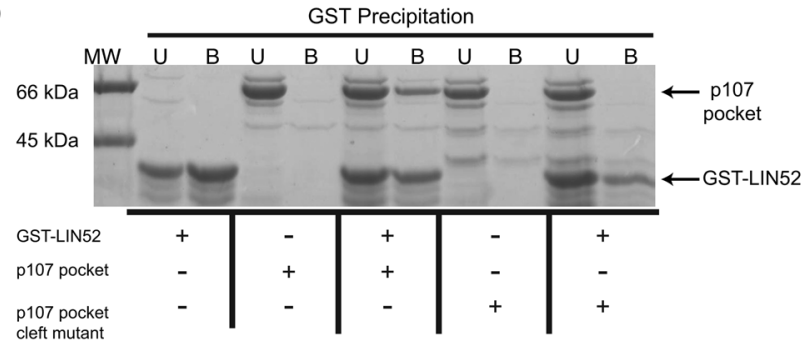

E

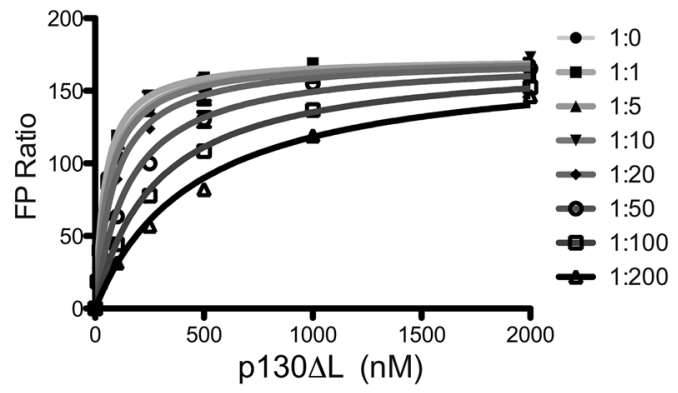

$\mathbf{F}$

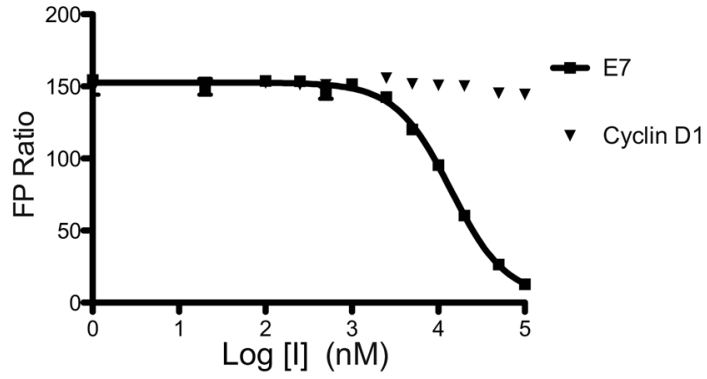

Figure 1. Direct association between LIN52 and p107/p130. Coprecipitation experiments performed with recombinant purified proteins. The indicated proteins were mixed and precipitated with the appropriate resin, and both unbound (U) and bound (B) fractions were analyzed using PAGE and Coomassie staining. $(A)$ Coprecipitation of full-length GST-p130 and GST-LIN52-HIS expressed in Sf9 cells using $\mathrm{Ni}^{2+}$-NTA resin. Treatment of the p130 with $\lambda$ phosphatase during purification increases the amount of p130 appearing in the bound fraction. (B) Coprecipitation of the untagged $\mathrm{p} 130 \Delta \mathrm{L}$ pocket domain expressed in Sf9 cells with GST-LIN52 ${ }^{13-45}$ using GS4B sepharose resin. Mutation of S28 in LIN52 or its treatment with $\lambda$ phosphatase weakens the $\mathrm{p} 130 \Delta \mathrm{L}$ association. $(C)$ Same as $B$ but with a $\mathrm{p} 107 \Delta \mathrm{L}$ pocket domain. $(D)$ An experiment similar to that in B but using a p107 pocket domain (loops intact) and an LxCxE cleft (I931A, N935A, and V939A) mutant. (E) A fluorescence polarization (FP) assay demonstrating inhibition of the LIN52-p130 association by a human papillo-

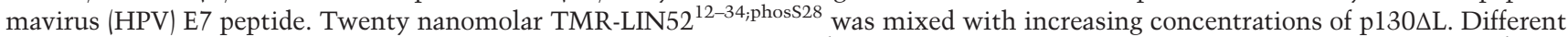
saturation curves are at the indicated molar ratio of TMR-LIN52 $2^{12-34 ; \text { phosS28 }}$ to E $7^{21-29}$ peptide. The affinity of TMR-LIN52 ${ }^{12-34 ; \text { phosS28 }}$ in the absence of $E 7^{21-29}$ is $K_{\mathrm{d}}=53 \pm 2 \mathrm{nM}$. $(F)$ FP measurements made of $10 \mathrm{nM}$ TMR-LIN52 ${ }^{12-34 ; \text { phosS28 }}$ in the presence of saturating $(2000 \mathrm{nM}) \mathrm{p} 130 \Delta \mathrm{L}$ and increasing concentrations of $\mathrm{E} 7^{21-29}$ peptide (squares) as the inhibitor (I). As a negative control, a peptide corresponding to the $\mathrm{N}$ terminus of Cyclin D1 (residues 1-17) was used (triangles). This peptide does not associate with p130 $\Delta \mathrm{L}$ (Supplemental Fig. 5).

The DREAM complex is perturbed in cervical cancer cells infected with human papillomavirus type 16 (HPV16), and knockdown of the oncoprotein HPV16 E7 rescues DREAM assembly and promotes cell cycle arrest (Nor Rashid et al. 2011). To determine whether HPV16 E7 can inhibit the direct LIN52 association with the p130 pocket domain, we used a fluorescence polarization (FP) competition assay. A LIN52 $2^{12-34 ; p h o s S 28}$ peptide was labeled with a tetramethylrhodamine (TMR) dye and mixed with increasing amounts of $\mathrm{p} 130 \Delta \mathrm{L}$ to obtain FP saturation curves. Addition of $\mathrm{E} 7^{21-29}$ peptide to the binding reaction shifted the curves such that $\mathrm{p} 130 \Delta \mathrm{L}$ appeared to bind with weaker affinity (Fig. 1E). We then quantified the E7 peptide inhibition $\left(K_{\mathrm{i}}=170 \pm 50 \mathrm{nM}\right)$ by displacing labeled LIN52 ${ }^{12-34 ; \text { phosS28 }}$ peptide in the FP assay (Fig. 1F). E7 ${ }^{21-29}$ contains an LxCxExL motif and inhibits LIN52 from interacting with p130, indicating that E7 disrupts DREAM by competitive inhibition at the LxCxE cleft of p130. 
Guiley et al.

\section{Crystal structures of LIN52-p107and E7-p107 complexes}

To identify the molecular interactions involved in DREAM assembly and oncoprotein-facilitated disruption, we solved the crystal structures of the p107 $\Delta \mathrm{L}$ pocket domain bound to a phosphorylated synthetic LIN52 peptide (LIN52 ${ }^{12-34 ; \text { phoss28 }}$ ) at $2.3 \AA$ and bound to an E7 $\left(E 7^{21-29}\right)$ peptide at $2.2 \AA$ (Fig. 2; Table 1). The structures reveal that the overall fold of the p107 pocket domain is similar to that of $\mathrm{Rb}$, consisting of two helical subdomains called the A and B boxes. Each subdomain contains a fivehelix cyclin fold flanked by additional helices that form the A-B interface or the LxCxE interface or cover hydrophobic surfaces. As with previous $\mathrm{Rb}$ pocket domain structures (Lee et al. 1998, 2002; Xiao et al. 2003; Balog et al. 2011), most residues in the central loop between the two subdomains were left out of the crystallized construct, and the residues that remain are not visible in the electron density.

Structural alignment of the p107 and Rb pocket domains (Protein Data Bank [PDB]: 3POM) shows a root mean square deviation (RMSD) in the $\mathrm{Ca}$ position of only $1.2 \AA$ (Supplemental Fig. 2A). While most secondary structural elements compare, relative to $\mathrm{Rb}$, the p107 A-box has two additional small helices $\left(a 4^{\prime}\right.$ and $\left.\alpha 10^{\prime}\right)$. These helices consist of sequences for which the corresponding electron density in $\mathrm{Rb}$ was not observable. a10' occurs at the $\mathrm{C}$ terminus of the A-box and creates additional A-B interface contacts through packing against a11. The E7 peptide binds to the LxCxE cleft in the B-box of p107 as previously observed in the Rb-E7 complex structure (Fig. 2; Supplemental Fig. 2B; Lee et al. 1998). The similar specific contacts made are consistent with the high se- quence homology between $\mathrm{Rb}$ and $\mathrm{p} 107$ within the $\mathrm{LxCxE}$ cleft.

In the p107 $\Delta$ L-LIN52 $2^{12-34 ; p h o s S 28}$ structure, LIN52 binds at the LxCxE cleft, consistent with our coprecipitation experiments. The LIN52 peptide binds with an LxSxExL (residues 18-24) motif and makes a set of interactions similar to that of the E7 peptide (Figs. 2, 3A; Supplemental Fig. 3). However, several striking differences arise from the presence of the more polar hydroxyl group in the LIN52 serine side chain. S20 occupies the place in the sequence analogous to that of the cysteine in the canonical E7 peptide $\operatorname{LxCxEx} \varphi$ motif. C24 in the E7 peptide fits in a hydrophobic pocket formed by F861 and Y849. In contrast, S20 in LIN52 makes hydrogen bonds with the K853 and Y849 side chains. The positions of both the F861 and Y849 side chains are changed in the LIN52 complex such that the F861 phenyl ring is flipped out toward solvent. Whereas the E7 peptide E26 side chain makes hydrogen bonds with the backbone of F861 and Q862, the LIN52 E22 side chain is occluded from the analogous position by the flipped-out F861 side chain. These structural differences suggest that the LIN52 serine-containing motif binds with weaker affinity than the canonical E7 motif.

The S28 phosphoserine side chain in LIN52 binds a positively charged pocket in p107 consisting of R869, S876, Y879, and R880 (Fig. 2). These p107 side chains are highly conserved in p107 and p130 paralogs but not in Rb (Fig. $3 \mathrm{~A})$. Rb notably has F739 at the Y879 position in p107 and lacks the phenolic hydroxyl group that hydrogenbonds with the LIN52 phosphate. The lack of the phosphate-binding pocket in $\mathrm{Rb}$ supports and explains previous observations that the DREAM complex does not assemble

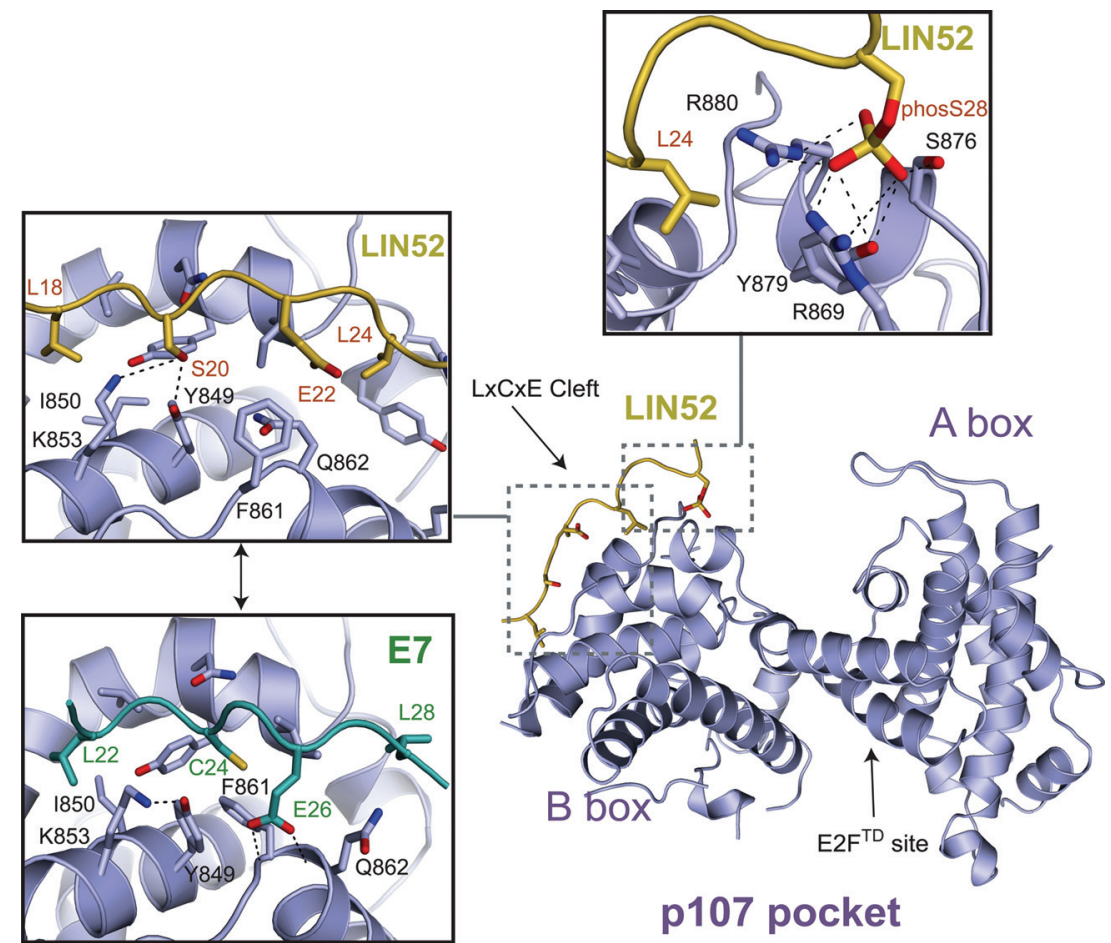

Figure 2. Crystal structures of the p107 pocket domain in complex with LIN52 $2^{12-34 ; \text { phoss } 28}$ and $\mathrm{E} 7^{21-29}$. (Insets, left) The LIN52 and E7 peptides both bind at the LxCxE cleft. (Inset, top) The LIN52 association is mediated by the S28 phosphate, which contacts a p107/ p130-specific binding pocket. 
Table 1. X-ray crystallography data collection and refinement statistics for crystals containing $\mathrm{p} 107 \Delta \mathrm{L}$ and the indicated peptide

\begin{tabular}{|c|c|c|c|}
\hline & $\mathrm{E} 7^{21-29}$ & LIN52 ${ }^{12-34 ; p h o s S 28}$ & LIN52 ${ }^{12-34 ; P 29 A ; ~ p h o s S 28 ~}$ \\
\hline \multicolumn{4}{|l|}{ Data collection } \\
\hline Space group & $\mathrm{C} 2_{1}$ & $\mathrm{C} 222_{1}$ & $\mathrm{C} 222_{1}$ \\
\hline \multicolumn{4}{|l|}{ Cell dimensions } \\
\hline$a, b, c$ & $99.7,76.6,74.7$ & $75.4,101.1,140.7$ & $74.8,100.5,142.8$ \\
\hline$\alpha, \beta, \gamma$ & $90,120.3,90$ & $90,90,90$ & $90,90,90$ \\
\hline Resolution & $57.2 \AA-2.2 \AA$ & $60.5 \AA-2.3 \AA$ & $71.4 \AA-2.4 \AA$ \\
\hline Total reflections & 48,201 & 159,897 & 112,012 \\
\hline Unique reflections & 21,552 & 24,252 & 21,397 \\
\hline$I / \sigma$ & $8.6(2.1)$ & $7.1(2.2)$ & $6.6(1.8)$ \\
\hline Completeness & $93.2 \%(94.4 \%)$ & $99.5 \%(97.9 \%)$ & $99.3 \%(97.9 \%)$ \\
\hline Redundancy & $2.2(2.2)$ & $6.6(6.4)$ & $5.2(5.4)$ \\
\hline$R_{\text {pim }}$ & $5.8 \%(25.2 \%)$ & $7.0 \%(39.2 \%)$ & $8.3 \%(44.2 \%)$ \\
\hline $\mathrm{CC}^{1 / 2}$ & $0.992(0.759)$ & $0.991(0.556)$ & $0.987(0.472)$ \\
\hline \multicolumn{4}{|l|}{ Refinement } \\
\hline Resolution & $57.2 \AA-2.2 \AA$ & $60.5 \AA-2.3 \AA$ & $71.4 \AA-2.4 \AA$ \\
\hline Number of reflections & $21,552(2171)$ & $24,232(2297)$ & $21,369(2084)$ \\
\hline$R_{\text {work }}$ & $18.4 \%(21.9 \%)$ & $19.9 \%(27.4 \%)$ & $19.5 \%(26.9 \%)$ \\
\hline$R_{\text {free }}$ & $24.0(26.9 \%)$ & $24.2 \%(30.0 \%)$ & $24.2 \%(33.6 \%)$ \\
\hline Number of atoms & 3008 & 2970 & 3082 \\
\hline Protein & 2877 & 2849 & 2934 \\
\hline Water & 111 & 95 & 128 \\
\hline \multicolumn{4}{|l|}{ RMSDs } \\
\hline Bond lengths & 0.005 & 0.005 & 0.007 \\
\hline Bond angles & $0.87^{\circ}$ & $0.93^{\circ}$ & $1.23^{\circ}$ \\
\hline \multicolumn{4}{|l|}{ Average B factor } \\
\hline Overall & $36.00 \AA^{2}$ & $61.30 \AA^{2}$ & $52.70 \AA^{2}$ \\
\hline $\mathrm{p} 107 \Delta \mathrm{L}$ & $34.53 \AA^{2}$ & $59.10 \AA^{2}$ & $50.25 \AA^{2}$ \\
\hline Peptide & $66.10 \AA^{2}$ & $129.12 \AA^{2}$ & $92.95 \AA^{2}$ \\
\hline \multicolumn{4}{|l|}{ Ramachandran analysis } \\
\hline Favored & $97.4 \%$ & $96.0 \%$ & $96.0 \%$ \\
\hline Outliers & $0.0 \%$ & $0.3 \%$ & $0.3 \%$ \\
\hline
\end{tabular}

Values in parenthesis are for the high-resolution shell.

with Rb (Litovchick et al. 2007; Pilkinton et al. 2007; Schmit et al. 2007; Forristal et al. 2014). The intervening amino acids between the LxSxExL sequence and phosS28 loop out from the p107 domain and do not make any direct contacts (Fig. 2). We also solved a crystal structure of p107 $\mathrm{L}$ in complex with a mutant peptide (LIN52 ${ }^{12-34}$; P29A;phosS28) that binds with higher affinity (Tables 1, 2). The electron density corresponding to the LIN52 peptide is stronger in this structure and allows for observation of additional interactions between W32 in LIN52 and E863, M865, R869, and Y879 in p107 (Supplemental Fig. 3).

While p107 and p130 loss in genetic models does not readily lead to tumors, there is evidence that p107 and p130 have tumor suppression function and can compensate for $\mathrm{Rb}$ loss in certain contexts (Dannenberg et al. 2004; Wirt and Sage 2010). The cBioPortal for Cancer Genomics catalogs a number of missense and nonsense mutations in both p107 and p130 that occur in human cancer samples (Gao et al. 2013). We found that 31 of the currently reported missense mutations for p107 are within the structured pocket domain (Supplemental Fig. 4). Based on the location of these residues in our crystal structure, we predict that 21 of these 31 mutations would destabilize the protein and likely result in functional loss. Three other mutations map to the E2F-binding surface based on the analogous Rb-E2F structure (Lee et al. 2002; Xiao et al. 2003). Notably, two mutations (R880I and Y934C) and an analogous p130 mutation map to the LIN52 interface, and we found that these p107 mutations weaken the LIN52 ${ }^{12-34 ; \text { phosS28 }}$ peptide affinity (Supplemental Fig. 4). These observations support the idea that p107/p130-dependent growth control through both E2F inhibition and DREAM function plays an important role in tumor suppression.

\section{LIN52 S28 phosphorylation increases LxSxExL affinity}

Our structural data suggest that the LxSxExL sequence in LIN52 binds to the pocket domain with lower affinity than a canonical LxCxExL sequence and that phosphorylation increases affinity specifically in p107 and p130 to make a more stable complex. We tested these ideas by quantitatively measuring the affinity of different LIN52 peptides using isothermal titration calorimetry (ITC) (Fig. 3B; Supplemental Fig. 5). LIN52 ${ }^{12-34 ; \text { phosS28 }}$ binds p107 $\Delta$ L with an affinity of $K_{\mathrm{d}}=1.4 \mu \mathrm{M} \pm 0.9 \mu \mathrm{M}$ and $\mathrm{p} 130 \Delta \mathrm{L}$ with a similar affinity of $K_{\mathrm{d}}=1.0 \mu \mathrm{M} \pm 0.1 \mu \mathrm{M}$. An unphosphorylated LIN52 $2^{12-34}$ peptide binds $\mathrm{p} 107 \Delta \mathrm{L}$ with weaker affinity $\left(K_{\mathrm{d}}=5.9 \mu \mathrm{M} \pm 0.9 \mu \mathrm{M}\right)$. Mutation of $\mathrm{S} 20$ to a cysteine 
Guiley et al.

A

$\begin{array}{lll} & & 15 \\ \text { LIN52 } & \text { Human } & \text { EASLLSFEKLDRASPDLWPEQ } \\ & \text { Mouse } & \text { EASLLSFEKLDRASPDLWPEQ } \\ & \text { Chicken } & \text { EASLLSFEKLDRASPDLWPEQ } \\ & \text { Zebrafish } & \text { ESSLISLENLDRASPDLWPEQ } \\ & \text { Frog } & \text { ETSLLSFEKLDRASPDLWPEQ } \\ & \text { Fly } & \text { EDELISMETLR-PSPVQWPER } \\ & \text { Worm } & \text { KKMLECTETMPEESEPVPMKC } \\ \text { E7 } & \text { HPV } & \text { 21 DLYCYEQLN 29 }\end{array}$

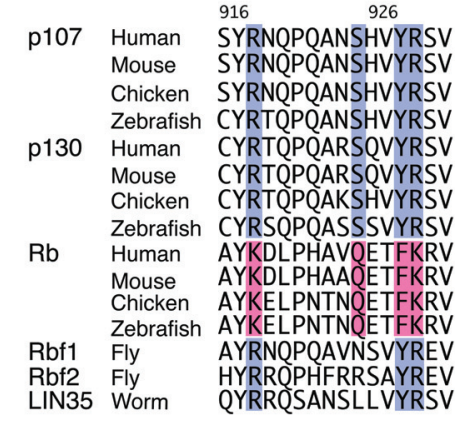

B

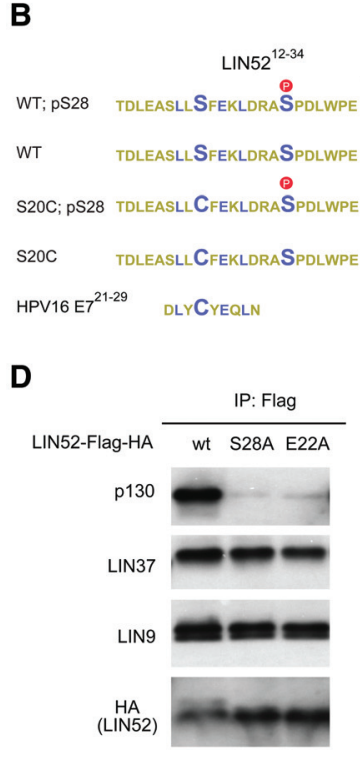

C

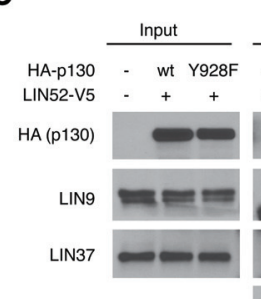

V5 (LIN52)
E

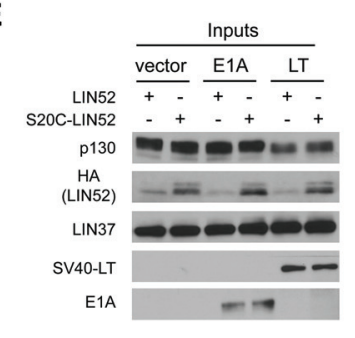

Figure 3. Role of the LxSxExL motif and S28 phosphorylation on LIN52-p107/p130 association. (A) Alignment of LIN52 (left) and pocket protein (right) sequences. The LIN52 LxSxExLxxxpS motif and S28 phosphate-binding residues are highlighted. $(B)$ Isothermal titration calorimetry (ITC) affinity measurements of LIN52 $2^{12-34}$ variants and $E 7^{21-29}$ binding to pocket proteins. (*) Value previously reported (Lee et al. 1998). (C) T98G cells were cotransfected with LIN52-V5 and the indicated HA-p130, extracts were immunoprecipitated with an anti-V5 antibody, and proteins were detected with the appropriate antibodies in a Western blot. The band in the LIN9 blot marked with an asterisk is nonspecific. $(D)$ T98G cells stably expressing the wild-type (wt) or mutant LIN52-Flag-HA alleles were serum-starved for $48 \mathrm{~h}$, and the coimmunoprecipitation was performed as in $C$ except with an anti-Flag antibody. (E) As in $C$, wild-type (wt) and S20C mutant LIN52-Flag-HA and viral proteins SV40 large T antigen (LT) and adenovirus E1A were transiently expressed in cycling T98G cells as indicated. Band intensities for the immunoprecipitated HA-LIN52 and p130 were quantified, and the p130/LIN52 ratio is plotted. Error bars are standard deviations for two different replicates of the experiment. increases affinity for $\mathrm{p} 107 \Delta \mathrm{L}\left(\mathrm{LIN} 52^{12-34 ; \mathrm{S} 20 \mathrm{C}} ; K_{\mathrm{d}}=0.120\right.$ $\mu \mathrm{M} \pm 0.007 \mu \mathrm{M})$. The sensitivity of the canonical $\operatorname{LxCxEx} \varphi$ motif to a serine substitution has been observed previously in the case of the E7 peptide and Rb (Jones et al. 1990). We found that the LIN52 ${ }^{12-34 ; S 20 C}$ affinity for $\mathrm{p} 107 \Delta \mathrm{L}$ is similar to the affinity of the HPV16 E $7^{21-29}$ peptide for $\mathrm{p} 107 \Delta \mathrm{L}\left(K_{\mathrm{d}}=0.16 \mu \mathrm{M} \pm 0.04 \mu \mathrm{M}\right)$. S28 phosphorylation in the context of the S20C mutation still increases affinity (LIN52 $12-34 ;$ S20C; phosS28; $K_{\mathrm{d}}=0.021 \mu \mathrm{M} \pm 0.004 \mu \mathrm{M}$ ) such that it is tighter than the wild-type phosphorylated LIN52 sequence.

No binding was observable upon mixing of either the LIN52 $2^{12-34}$ or LIN52 ${ }^{12-34 ; \text { phosS28 }}$ peptide with $\mathrm{Rb}$. The LIN52 $2^{12-34 ; S 20 C}$ peptide $\left(K_{\mathrm{d}}=0.3 \mu \mathrm{M} \pm 0.1 \mu \mathrm{M}\right)$ binds $\mathrm{Rb}$ with an affinity similar to that of p107; however, phosphorylation results in no additional increase in affinity (LIN52 ${ }^{12-34 ; S 20 C ; p h o s S 28} ; K_{d}=0.3 \mu \mathrm{M} \pm 0.1 \mu \mathrm{M}$ ). This result corroborates the lack of a phosphate-binding pocket in $\mathrm{Rb}$. We also mutated the residues in $\mathrm{p} 107 \Delta \mathrm{L}$ that contact LIN52 phosS28 in the crystal structure such that they resemble the $\mathrm{Rb}$ sequence $(\mathrm{R} 869 \mathrm{~K}, \mathrm{~S} 876 \mathrm{Q}, \mathrm{Y} 879 \mathrm{~F}$, and R880K). LIN52 and LIN52 ${ }^{12-34 ; S 20 C}$ bind the Rblike mutant (p107 $\left.{ }^{\text {mutant }}\right)$ with weaker affinity compared with $\mathrm{p} 107 \Delta \mathrm{L}$, and phosphorylation does not enhance affinity (Fig. 3B). The $E 7^{21-29}$ peptide binds p107 ${ }^{\text {mutant }}$ and $\mathrm{p} 107 \Delta \mathrm{L}$ with similar affinities, which is consistent with a lack of interaction between E7 and the phosphate pocket.

The fact that LIN52 $2^{12-34}$ and LIN52 $2^{12-34 ; \text { phosS28 }}$ bind p $107^{\text {mutant }}$ with greater affinity than $\mathrm{Rb}$ suggests that p107-specific interactions other than the phosphatebinding pocket stabilize LIN52 association. One possible explanation observed in the crystal structure is the presence of I850 in p107. I850 contacts Y849 and stabilizes the Y849 position for hydrogen bonding to S20 in LIN52

Table 2. Affinity of LIN52 peptides for the p107 pocket domain (see Supplemental Fig. 5 for exemplary ITC traces)

\begin{tabular}{|c|c|}
\hline Peptide & $\mathrm{p} 107 \Delta \mathrm{L}$ affinity \\
\hline LIN52 ${ }^{12-34 ; \text { phosS28 }}$ & $1.4 \mu \mathrm{M} \pm 0.8 \mu \mathrm{M}$ \\
\hline LIN52 $2^{12-34 ; L 18 A ; p h o s S 28}$ & $14.9 \mu \mathrm{M} \pm 0.1 \mu \mathrm{M}$ \\
\hline LIN52 $2^{12-34 ; L 24 A_{;} \text {phosS28 }}$ & $7.4 \mu \mathrm{M} \pm 0.9 \mu \mathrm{M}$ \\
\hline LIN52 ${ }^{12-34 ; E 22 A ; p h o s S 28}$ & $5.5 \mu \mathrm{M} \pm 0.3 \mu \mathrm{M}$ \\
\hline LIN52 $2^{12-34 ;+A 28 ; p h o s S 29}$ & $1.7 \mu \mathrm{M} \pm 0.3 \mu \mathrm{M}$ \\
\hline LIN52 ${ }^{12-34 ;-A 27 ; p h o s S 27}$ & $0.126 \mu \mathrm{M} \pm 0.002 \mu \mathrm{M}$ \\
\hline LIN52 ${ }^{12-34 ; P 29 A ; p h o s S} 28$ & $0.035 \mu \mathrm{M} \pm 0.003 \mu \mathrm{M}$ \\
\hline
\end{tabular}


(Fig. 2). In contrast, G710 at the corresponding position in $\mathrm{Rb}$ cannot play the same stabilizing role and is likely a source of the lower $\mathrm{Rb}$ affinity for the noncanonical LxSxExL motif relative to p107/p130.

We tested the significance of the p107/p130-specific phosS28-binding site for DREAM assembly in cells (Fig. 3C). T98G cells were cotransfected with V5-tagged LIN52 and either wild-type HA-p130 or HA-p130 with a Y928F mutation (equivalent to Y879F in p107). LIN52V5 was precipitated with an anti-V5 antibody, and we examined the amount of precipitated p130 by Western blot. LIN52 coprecipitated less Y928F mutant p130 protein than wild-type, supporting the requirement of an intact phosphate-binding pocket as observed in the crystal structure for DREAM assembly.

\section{The LXSXExL sequence motif is critical for DREAM assembly}

To explore further the important elements of the LIN52 LxSxExL-binding motif, we measured the affinity of different LIN52 $2^{12-34}$ peptides for the p107 pocket domain using the ITC assay (Table 2; Supplemental Fig. 5). Both the $\mathrm{L} 18 \mathrm{~A}\left(K_{\mathrm{d}}=14.9 \mu \mathrm{M} \pm 0.1 \mu \mathrm{M}\right)$ and $\mathrm{L} 24 \mathrm{~A}\left(K_{\mathrm{d}}=7.4 \mu \mathrm{M} \pm\right.$ $0.9 \mu \mathrm{M}$ ) consensus mutations in LIN52 reduce affinity. Although E22 in LIN52 does not make any interactions with p107 in the crystal structure (Fig. 2), we also found that an E22A mutation $\left(K_{\mathrm{d}}=5.5 \mu \mathrm{M} \pm 0.1 \mu \mathrm{M}\right)$ reduces affinity fourfold compared with wild type $\left(K_{\mathrm{d}}=1.4 \mu \mathrm{M} \pm 0.8 \mu \mathrm{M}\right)$. We suggest that, in solution, there is an additional alternate conformation in equilibrium that resembles the E7 peptide conformation but is less stable because of the buried S20 hydroxyl group.

We also measured the effects of moving the position of phosS28 relative to the LxSxExL motif. Addition of an alanine to the intervening three residues results in similar

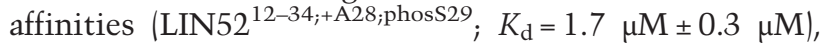
while the peptide with A27 deleted binds with 10 -fold tighter affinity (LIN52 ${ }^{12-34 ;-A 27 ; p h o s S 27} ; K_{\mathrm{d}}=0.126 \mu \mathrm{M} \pm$ $0.002 \mu \mathrm{M})$. This observation is consistent with a lack of interactions between the intervening sequence and pocket domain (Fig. 2). The tighter affinity of the shorter sequence may result from a reduced entropic penalty for binding. Many kinases phosphorylate substrates bearing an (S/T)P motif, which include DYRK1A and the CDKs (Ubersax and Ferrell 2007). We tested a LIN52 phosS28 P29A mutant to determine whether p107 binding is also dependent on this motif. The mutant has a higher affinity (LIN52 ${ }^{12-34 ; P 29 A ; p h o s S 28} ; K_{\mathrm{d}}=0.035 \mu \mathrm{M} \pm 0.003 \mu \mathrm{M}$ ) than wild-type, suggesting that the proline is required for kinase recognition of $\mathrm{S} 28$ but is not preferred at this position for pocket binding.

To determine whether the $\mathrm{p} 130$ pocket association with the LIN52 LxSxExL motif is required for DREAM assembly in cells, we generated LIN52-HA-Flag mutants stably expressed in T98G cells. We then immunoprecipitated the Flag sequence and examined the coprecipitation of p130 by Western blot. When either E22 or S28 is mutated in LIN52, p130 binding is diminished, while binding of the MuvB proteins LIN37 and LIN9 is preserved (Fig. 3D). We also tested the stabilizing effect of an S20C mutant on the LIN52-p130 complex by coprecipitation (Fig. 3E). The LIN52-HA-Flag S20C mutant expresses at a higher level than wild type but does not coprecipitate a relatively greater amount of p130. However, when coexpressed with either E1A or large T-antigen viral proteins, both of which contain LxCxEx $\varphi$ sequences, LIN52 S20C does coprecipitate a relatively greater amount of p130 than wild type. We conclude that the wild-type sequence is sufficient to coprecipitate p130, but, when challenged with high-affinity viral proteins, the increase in affinity from the S20C mutation allows LIN52 to better compete with E1A and large T-antigen for p130 binding. This result emphasizes how the weaker LxSxExL motif in LIN52, even with the addition of S28 phosphorylation, enables DREAM disassembly by competitor viral oncoproteins.

\section{$B-M y b$ requires LIN52 to bind to MuvB but does not compete with 130}

We next investigated the determinants of B-Myb binding to MuvB in order to compare the mechanisms of DREAM and MMB assembly. The evolutionarily conserved MuvB proteins in the Drosophila melanogaster DREAM complex were found to interact with the $\mathrm{C}$ terminus of $\mathrm{B}$ Myb (Andrejka et al. 2011). To test whether this association is direct and conserved in the human proteins, we performed a series of precipitation experiments with recombinant B-Myb and MuvB proteins from Sf9 cells (Fig. 4). We reconstituted the core MuvB subcomplex by coexpressing GST-LIN9 ${ }^{94-542}$, which lacks its poorly conserved and putative unstructured $\mathrm{N}$ terminus, along with full-length GST-LIN37, Strep-RBAP48, and GST-LIN52 as indicated. The purified complexes were then coprecipitated in the presence of the C terminus of B-Myb (GSTB-Myb $\left.{ }^{654-700}\right)$. We found that GST-B-Myb ${ }^{654-700}$ binds the MuvB subcomplex only in the presence of LIN52 (Fig. 4A). However, full-length GST-LIN52-HIS, which is sufficient to coprecipitate p130 (Fig. 1A), is not sufficient to coprecipitate GST-B-Myb ${ }^{654-700}$ (Fig. 4B). We conclude that LIN52 is necessary but not sufficient for B-Myb binding. The requirement for LIN52 could result from direct B-Myb-LIN52 contacts or because LIN52 is necessary for a properly structured MuvB core.

We next tested whether p130 and B-Myb compete for access to MuvB or can both bind simultaneously. We found that Strep-tagged RbAP48 together with the other components of the MuvB subcomplex coprecipitate both GST-B-Myb ${ }^{654-700}$ and $\mathrm{p} 130$ pocket when all components are mixed in the same solution (Fig. 4C). Increasing the amount of p130 does not change the amount of GST-B-Myb ${ }^{654-700}$ that coprecipitates, consistent with a lack of competition (Fig. 4C). We also found that GST-B$\mathrm{Myb}^{654-700}$ coprecipitates the p130 pocket if and only if the components of MuvB are present, demonstrating the presence of a complex that contains B-Myb ${ }^{654-700}$, the p130 pocket, and MuvB all together (Fig. 4D). Based on these observations that p130 and B-Myb can simultaneously bind MuvB and that they have different requirements for binding, we conclude that they have nonoverlapping 
Guiley et al.

A

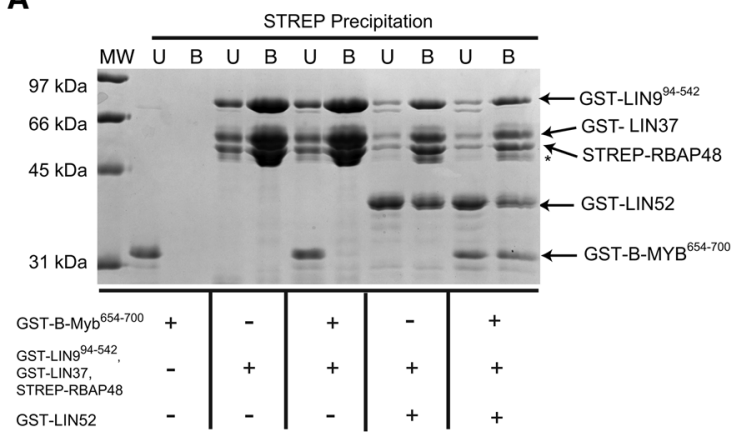

C

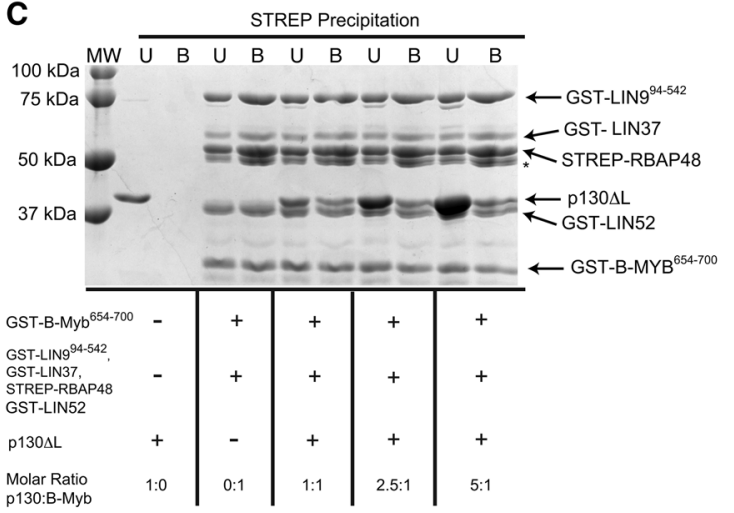

E

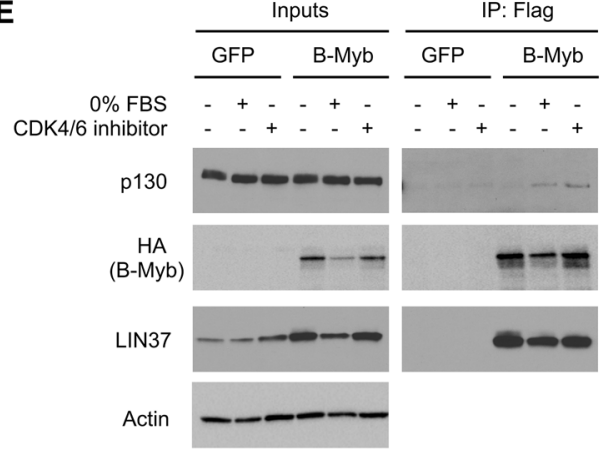

B

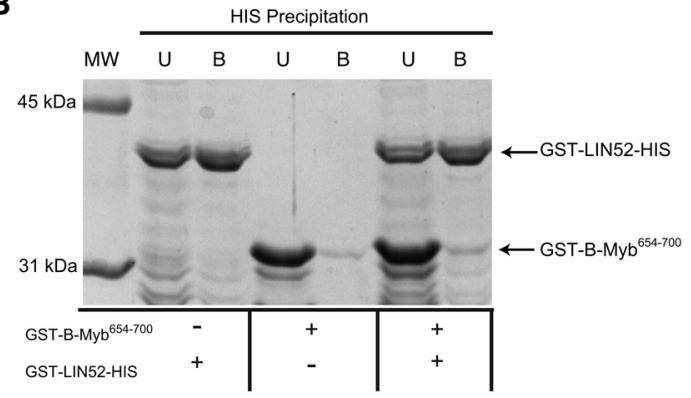

D

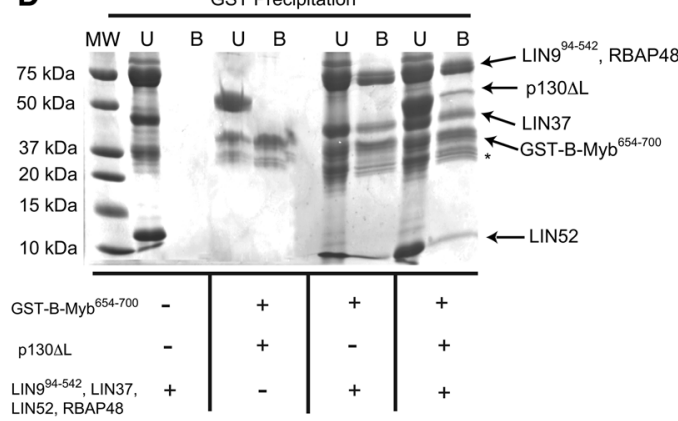

Figure 4. B-Myb and p130 bind distinct surfaces of MuvB. Coprecipitation experiments were conducted with recombinant proteins as in Figure 1. (A) Streptactin coprecipitation of Strep-tagged RbAP48, GST-LIN9 ${ }^{94-542}$, and GST-LIN37 with GST-B-Myb ${ }^{654-700}$ in the absence and presence of GST-LIN52 demonstrates the requirement of LIN52 for B-Myb-MuvB binding. The band marked with an asterisk is a GST-LIN9 ${ }^{94-542}$ degradation product. (B) Ni $^{2+}$-NTA fails to coprecipitate GST-B-Myb ${ }^{654-700}$ with GST-LIN52-HIS alone. (C) Streptactin coprecipitation of Strep-tagged RbAP48, GST-LIN9 ${ }^{94-542}$, GST-LIN37, and GST-LIN52 with GST-B-Myb ${ }^{654-700}$ in the presence of increasing amounts of $\mathrm{p} 130 \Delta \mathrm{L}$. The amount of coprecipitated GST-B-Myb ${ }^{654-700}$ does not change, demonstrating that the p130 pocket domain does not compete with B-Myb for MuvB binding. The band marked with an asterisk is a GST-LIN $9^{94-542}$ degradation product. $(D)$ GST-B-Myb ${ }^{654-700}$ coprecipitates the untagged p130 pocket domain only in the presence of the untagged MuvB components, indicating that both B-Myb and p130 can simultaneously bind MuvB. The bands marked with an asterisk show degradation products of GST-B-Myb ${ }^{654-700}$. (E) Association of p130 and MuvB with ectopically expressed B-Myb. BJ-hTERT fibroblasts stably expressing HA-Flag-tagged GFP (control) or B-Myb were incubated for $24 \mathrm{~h}$ in complete medium, in the medium without FBS, or in medium containing CDK4/6 inhibitor. Proteins of interest were detected by Western blot in the cell extracts (Inputs) and in the anti-Flag pull-downs (IP:Flag).

binding sites on the MuvB core. In order to demonstrate that full-length p130 and B-Myb associate together with MuvB in cells, we precipitated HA-Flag-B-Myb that is stably expressed in BJ-hTERT fibroblasts (Fig. 4E). We observed coprecipitation of endogenous LIN37 and p130 under conditions that support DREAM assembly, in- cluding serum starvation and Cdk4/6 inhibition with palbociclib (PD-0332991, Pfizer, Inc.). Although we cannot rule out a direct association between full-length p130 and $\mathrm{B}-\mathrm{Myb}$ in this experiment, the data are consistent with B-Myb coprecipitating p130 through a common MuvB core. 
CDK phosphorylation promotes DREAM disassembly

Components of the MuvB complex fail to associate with p107 and p130 in cycling cells; however, the mechanism of DREAM inhibition upon exit from quiescence has not been elucidated. Considering that LIN52 is found phosphorylated and unphosphorylated at S28 when bound to B-Myb during S phase (Litovchick et al. 2011), dephosphorylation of LIN52 S28 is unlikely the primary mechanism promoting DREAM disassembly. Our result that BMyb and p130 bind MuvB simultaneously also argues against a competitive mechanism for DREAM disassembly by which, upon expression, B-Myb displaces p130 from MuvB. Noting the coincident timing of Cdk activation and DREAM disassembly (Pilkinton et al. 2007), we tested directly whether Cdk activity correlated with p130 binding to MuvB. We found that the MuvB component LIN37 can coprecipitate a greater amount of p130 from the extracts of cycling T98G cells in the presence of the Cdk4/6 inhibitor (Fig. 5A). To observe the effect of Cdk inhibition on DREAM disassembly upon cell cycle entry, we released T98G cells from serum starvation and found that LIN37 coprecipitation of p130 persists to a greater extent in the presence of the Cdk4/6 inhibitor (Fig. 5B). In the absence of inhibitor, the loss of p130 coprecipitation, beginning at $10 \mathrm{~h}$, correlates with the disappearance of the hypophosphorylated p130 form (the lower band in the gel). These results demonstrate that Cdk activity in cells inhibits p130-MuvB association.

We asked whether Cyclin D1 could inhibit DREAM assembly by directly competing with the LIN52 interaction at the p130 LxCxE cleft. Cyclin D1 was previously proposed to bind the LxCxE cleft in the $\mathrm{Rb}$ pocket domain (Dowdy et al. 1993). However, we found in our FP assay (Fig. 1F) that a Cyclin D1 peptide does not displace LIN52 form p130 $\Delta$ L. We also titrated the Cyclin D1 peptide bearing its LxCxExE motif into p107 $\Delta \mathrm{L}$ and $\mathrm{p} 130 \Delta \mathrm{L}$ in the ITC assay and found no observable binding (Supplemental Fig. 5), suggesting that the Cyclin D1 sequence does not directly associate with the pocket domain. These results are supported by our ITC data and previous reports (Singh et al. 2005) that a hydrophobic residue is necessary at the downstream glutamic acid position in Cyclin D1.

We hypothesized that Cdk phosphorylation of $\mathrm{p} 130 /$ p107 inhibits the LIN52 interaction with the p130/p107 pocket domain. In support of this mechanism, we found that $\lambda$ phosphatase treatment of the partially phosphorylated p130 purified from Sf9 cells increased LIN52-p130 complex stability in a qualitative coprecipitation assay (Fig. 1A). We quantified the effect of p130 phosphorylation on LIN52 binding using the FP assay described in Figure 1E. The TMR-LIN52 $2^{12-34 ; \text { phosS28 }}$ peptide was mixed with increasing amounts of GST-p130 purified from Sf9 cells without treatment, with phosphatase treatment, and with kinase treatment. While phosphatase treatment increases the affinity 3.5 -fold, Cdk2 phosphorylation decreases the affinity nearly twofold, demonstrating that p130 phosphorylation weakens LIN52 binding (Fig. 5C). The observation of a change in affinity upon treatment with either enzyme reflects the partial phosphorylation of GST-p130 purified from Sf9 cells.

Our structural observation that phosphorylated LIN52 binds p107/p130 at the LxCxE cleft suggests that Cdk phosphorylation events resulting in occlusion of the LxCxE-site would inhibit DREAM assembly. Studies of inactive $\mathrm{Rb}$ have revealed phosphorylation-induced structural changes that block the LxCxE cleft (Rubin et al. 2005; Burke et al. 2012; Rubin 2013). We considered one mechanism in which phosphorylation of conserved sites in the linker between the $\mathrm{N}$-terminal $(\mathrm{RbN})$ and pocket domains results in $\mathrm{RbN}$-pocket docking (Burke et al. 2012). Alignment of the phosphorylated $\mathrm{Rb}$ structure with the p107-LIN52 complex suggests that an analogous closed conformation in p107/p130 would inhibit LIN52 binding (Fig. 5D). In the $\mathrm{Rb}$ structure, residues in $\mathrm{RbN}$ form hydrogen bonds and salt bridge interactions with $\mathrm{Rb}$ pocket residues; the homologous residues in the p107 pocket domain contact the LIN52 S28 phosphate in the structure presented here.

To determine whether CDK phosphorylation disrupts the DREAM complex through phosphorylation of sites in the putative p107/p130 interdomain linker, we examined the effect of p130 T401A and T417A mutation on MuvB binding in cycling U2OS cells. We expressed LIN52 together with p130 wild type and the phosphosite mutant and found that LIN52 coprecipitates a greater amount of the T401A/T417A double mutant (Fig. 5E). We also found that the p130 double mutant can coprecipitate a greater amount of endogenous LIN37 than wild type (Fig. 5F). In order to test the functional consequences of mutating Cdk sites, we transfected U2OS cells with wild-type p130 and the T401A/T417A phosphosite mutant and examined proliferation of cells using S-phase-specific Ki-67 staining similar to as previously described (Canhoto et al. 2000). We found that the T401A/T417A mutant induces a more potent growth arrest than wild type, which is consistent with stabilization of the DREAM complex (Fig. 5G). T401 and T417 phosphorylation have also been shown to be relevant for regulation of E2F4 activity (Farkas et al. 2002). Mutation of these sites may also influence p130-E2F4 affinity and contribute to the observed growth arrest by stabilizing E2F binding.

\section{Discussion}

Our structural and binding data support a model in which the DREAM complex is mediated by the direct association of LIN52 with the p107/p130 pocket (Fig. 5H). Assembly is promoted by DYRK1A phosphorylation of S28 in LIN52, while disassembly is induced by Cdk phosphorylation of sites in p107/p130 that promote structural changes to occlude the LIN52-binding surface. B-Myb binding is dependent on LIN52 and other members of the MuvB core and can occur simultaneously with p107/p130 binding in our assays with recombinant protein and in cells under conditions in which B-Myb is ectopically expressed and 
Guiley et al.
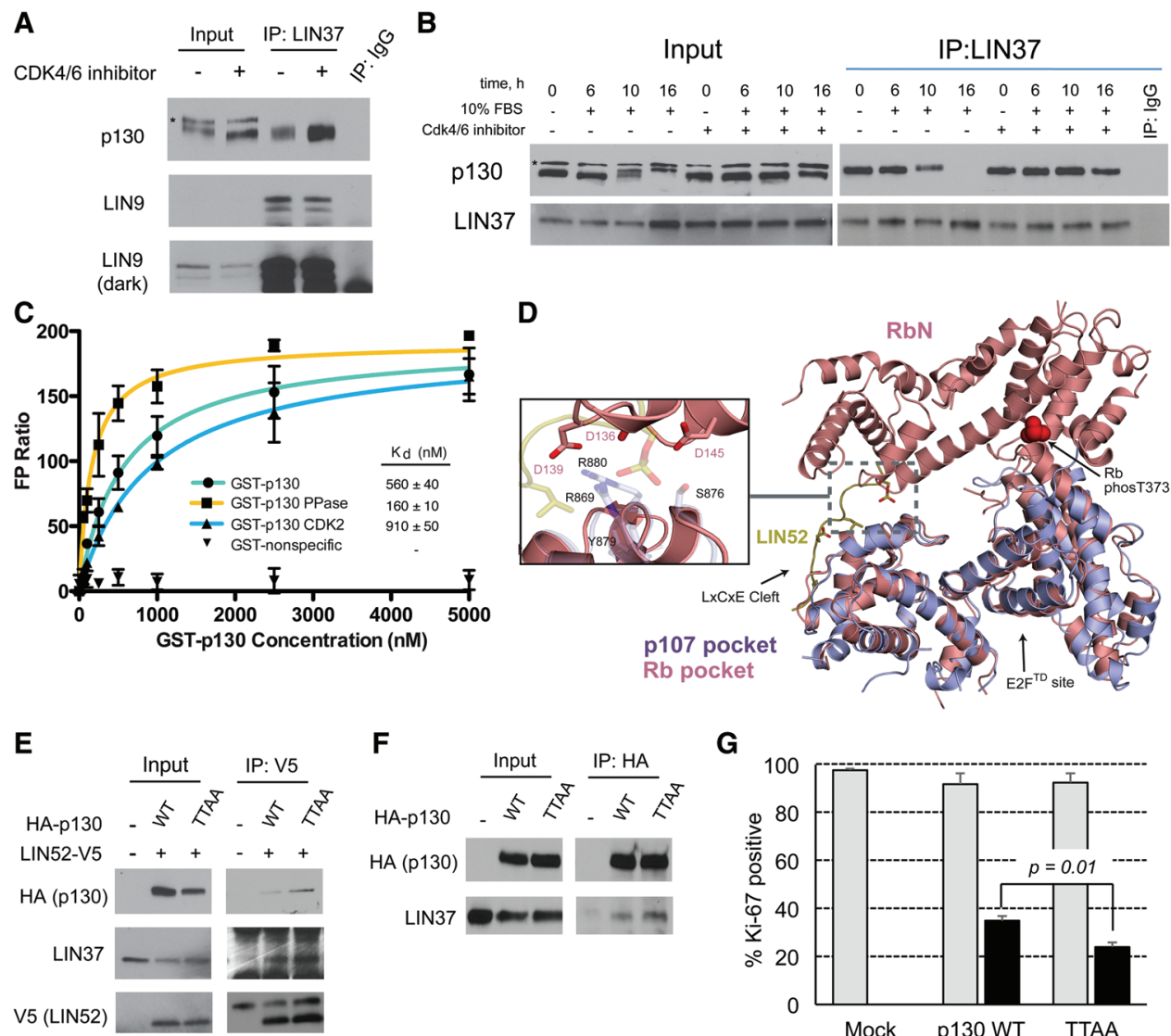

G

H
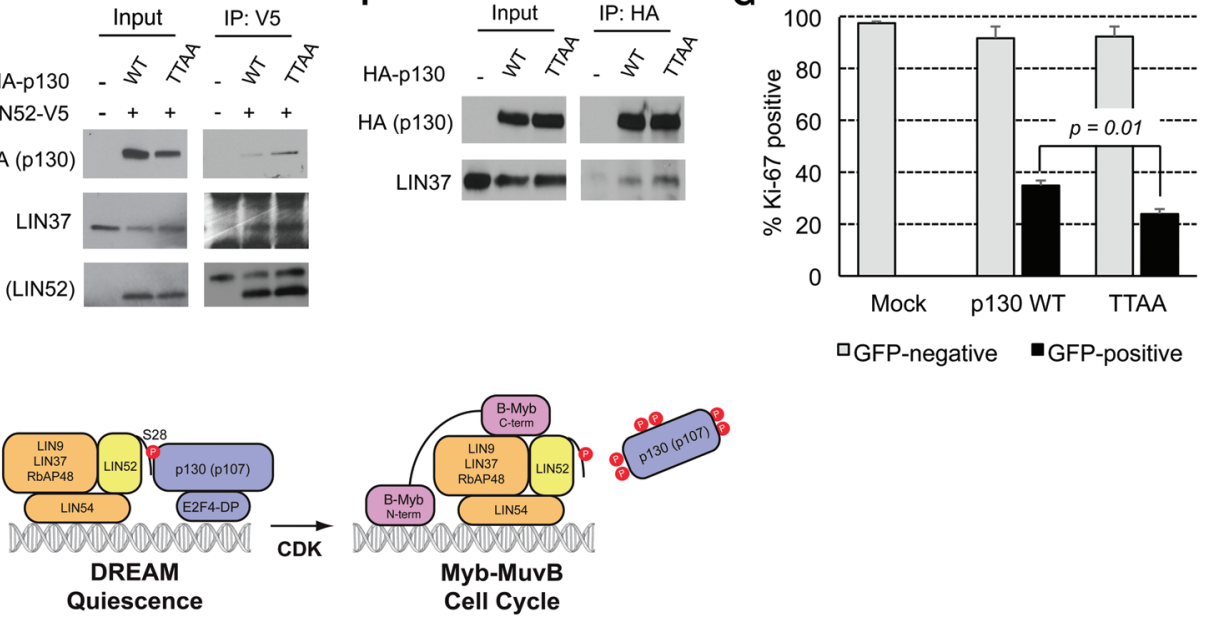

Figure 5. p130 phosphorylation weakens LIN52 binding and DREAM activity. (A) T98G cells were incubated for $24 \mathrm{~h}$ in the presence or absence of the CDK4/6 inhibitor palbociclib. Binding of p130 to LIN37 was determined by coimmunoprecipitation with an anti-LIN37 antibody and detection of proteins in a Western blot. The band marked with an asterisk in the p130 input blot is a nonspecific band. (B) T98G cells were serum-starved for $72 \mathrm{~h}$ and then released with addition of $10 \%$ FBS in the absence or presence of the Cdk4/6 inhibitor palbociclib. After harvesting cells at the indicated time points, extracts were immunoprecipitated with an anti-LIN37 antibody and probed for LIN37 and $\mathrm{p} 130$. The band marked with an asterisk in the p130 input blot is a nonspecific band. (C) FP binding assay of TMR-labeled LIN52 ${ }^{12-34 ;}$ phosS28 to GST-p130. The GST-p130 was purified from sf9 cells and used untreated (green line, circles), treated with $\lambda$ phosphatase (yellow line, squares), and treated with Cdk2 kinase (blue line, triangles). Purified GST alone was used as a negative control (inverted triangles). The expected effect of enzyme treatment was corroborated with a Phos-tag gel (Supplemental Fig. 1C). (D) Overlay of the LIN52 ${ }^{12-34 ; p h o s S 28}$ p107 structure and phosphorylated $\mathrm{Rb}^{55-787}$ structure (PDB: 4ELJ). Residues in p107 that bind the S28 phosphate in LIN52 (rendered as transparent blue sticks) are analogous to residues in the $\mathrm{Rb}$ pocket domain that bind the docked RbN domain (pink) when Rb is phosphorylated. (E) U2-OS cells were transfected with LIN52-V5 and the wild-type or T401A/T417A (TTAA) mutant HA-p130. Extracts were immunoprecipitated with anti-V5 antibody, and the indicated proteins were detected by Western blot. $(F)$ Same as in $E$ except an anti-HA antibody was used for immunoprecipitation. $(G)$ U2OS cells were cotransfected with wild-type or the T410A/T417A (TTAA) mutant of p130 and GFP as tracer. The expression of Ki-67 was determined by indirect immunofluorescence cell staining at $48 \mathrm{~h}$ after transfection. The graph shows the average values and standard deviations (error bars) of three replicate experiments in which at least 100 cells were counted per condition. The $P$-value evaluating statistical significance was calculated using a two-tailed Student's $t$-test. $(H)$ Model for DREAM complex disassembly and MMB complex assembly upon Cdk activation.

p130 is known to be hypophosphorylated. The fact that BMyb and p130 are not found together in complexes purified from mammalian cells is likely due to the coincidence of $\mathrm{B}-\mathrm{Myb}$ expression and p130 phosphorylation in those cells
(Litovchick et al. 2007). Complexes were purified from Drosophila cells containing both Myb and Rbf and may point to a distinct mechanism of regulation in lower metazoans. The D. melanogaster Rbf sequences notably lack 
conserved phosphorylation sites equivalent to T401 and T417 in p130, which further points to their importance in disassociating p130 from MuvB.

LIN52 accesses the LxCxE cleft of the pocket domain using a noncanonical and nonoptimal LxSxExL motif in combination with phosphorylation at S28. The weak affinity of the LxSxExL sequence sensitizes the association to regulatory phosphorylation by DYRK1A. Kinase phosphorylation acts as a switch because it increases LIN52 binding to submicromolar affinity. We note that in contrast to higher orthologs, Caenorhabditis elegans LIN52 maintains the canonical, tight-binding LxCxE motif and lacks the equivalent DYRK1A consensus surrounding the $\mathrm{S} 28$ residue. We predict that DREAM in C. elegans is not regulated equivalently by phosphorylation, and LIN52 and LIN35 constitutively form a stable complex. The LIN52 sequence in $D$. melanogaster resembles our

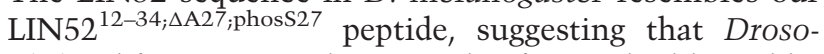
phila Rbf proteins and LIN52 also form a highly stable, phosphorylation-dependent interaction.

The requirement for LIN52 phosphorylation is an important source of specificity for p107 and p130 in DREAM assembly. Unlike Rb, the p107 and p130 pocket domains contain the proper phosphate-binding site. Phylogenetic sequence analysis of pocket proteins suggests that $\mathrm{Rb}$ appears more recently than p107 and p130, which are closer in sequence to pocket proteins such as LIN35 and Rbf in lower metazoans (van den Heuvel and Dyson 2008; Sadasivam and DeCaprio 2013). It is not clear then why $\mathrm{Rb}$ evolved such that it does not bind MuvB, although one possibility is that the $\mathrm{LxCxE}$ cleft in $\mathrm{Rb}$ must be reserved for some alternate unique function.

Despite their diverse cellular roles, the universal biochemical function of pocket proteins is to assemble protein complexes (Cobrinik 2005; Dick and Rubin 2013). It is estimated that several hundred proteins interact with $\mathrm{Rb}$ and its pocket protein paralogs, and the LxCxE cleft has been described as the key interface for these complexes (Morris and Dyson 2001). The crystal structure presented here of the p107-LIN52 complex provides the first structural insights into how cellular proteins contact the cleft. It implicates the LxSxExLxxxpS sequence as a novel binding motif that can be regulated by phosphorylation. We searched the Scansite 3 server (Obenauer et al. 2003) to identify other potential p107/p130-binding partners that use this motif and the motifs identified in our binding studies that bind the novel phosphate-binding pocket. We identified 203 proteins that matched our motifs, although only 13 are known to be phosphorylated on the consensus serine (Supplemental Table 1).

Cdk phosphorylation has been well characterized as a mechanism for inactivating pocket proteins, and both structural and functional studies have implicated the effects of phosphorylation on inhibiting pocket protein interactions (Cobrinik 2005; Rubin 2013). Our results here further support phosphorylation of p107/p130 as a mechanism of inactivating the DREAM complex by dissociating pocket proteins from the MuvB core. Mutation of conserved Cdk sites T401 and T417 enhances the growth arrest properties of p130 and stabilizes the DREAM com- plex (Fig. 5). Structural and sequence comparisons between $\mathrm{p} 107 / \mathrm{p} 130$ and $\mathrm{Rb}$ suggest that a conserved closed conformation that occludes the LxCxE cleft is induced by phosphorylation. We note that additional Cdk sites in p107/p130 may contribute to inhibition of LIN52 binding and that phosphorylation may also contribute to DREAM dissociation by inhibiting p107/p130 association with E2F proteins.

It has been suspected that cancer cells can in certain contexts avert the effect of cytotoxic treatments by entering quiescence. As an important mediator of cell cycle exit, DREAM may be an important additional target during chemotherapy. For example, cells from gastrointestinal stromal tumors enter quiescence following treatment with imatinib, and inhibition of DREAM assembly through genetic knockdown alternatively induces apoptosis (Boichuk et al. 2013). Our structural characterization of LIN52 association with p107 suggests that inhibitors of protein interactions at the LxCxE cleft in pocket proteins would likely block DREAM function in vivo. It is encouraging that only a short peptide corresponding to the E7 sequence is sufficient for inhibition of LIN52 association in vitro (Fig. 1F), and small molecule inhibitors of the E7 LxCxE-Rb interaction have been reported (Fera et al. 2012). Discovery of more potent chemical inhibitors of LxCxE-pocket binding may prove to be a viable strategy for preventing cancer cells from escaping to quiescence as a mechanism for surviving therapeutic treatment.

\section{Materials and methods}

Protein expression and peptides

A human Rb pocket with its loop deleted (residues N380-G581; K643-R787), a p107 pocket (T391-Q972), p107_L (T391-T599; N780-I887; K924-Q972), and p130 $\Delta$ L (H424-D632; N828K935; E999-Q1049) were expressed and purified from E. coli BL21 cells as GST fusion proteins. Cells were induced with 1 $\mathrm{mM}$ IPTG and grown overnight at $20^{\circ} \mathrm{C}$. Lysates were first purified by GS4B affinity chromatography. The elution fraction was then subjected to TEV protease cleavage and dialyzed overnight in $25 \mathrm{mM}$ Tris, $200 \mathrm{mM} \mathrm{NaCl}, 1 \mathrm{mM}$ DTT, and $0.5 \mathrm{mM}$ EDTA ( $\mathrm{pH}$ 8.0). The protein was then passed over GS4B affinity resin again to remove free GST, concentrated, and stored in a buffer containing $20 \mathrm{mM}$ Tris, $200 \mathrm{mM} \mathrm{NaCl}, 1 \mathrm{mM} \mathrm{DTT}$, and $20 \%$ glycerol ( $\mathrm{pH} 8.0)$.

LIN52, LIN37, RBBP48, LIN9, B-Myb, and full-length p130 were expressed and purified from Sf9 cells (Expression Systems) using baculovirus vectors. Proteins were purified as described above, and the GST-free samples were passed over a Superdex200 column that was equilibrated in the dialysis buffer following TEV cleavage. p130 was phosphatase-treated with $1 \% \lambda$ phosphatase by mass using the manufacturer's protocol (New England Biolabs). Cdk2 treatment was performed as described (Burke et al. 2010) except the Cdk2 activator Speedy was used instead of a cyclin activator. Following treatment, GST-p130 was separated from the enzymes using a Superdex-200 column.

The LIN52 $2^{12-34 ; \text { phosS28 }}$ and E $7^{21-29}$ peptides used for crystallization were synthesized by BioPeptide LLC. The LIN52 ${ }^{12-34 ; P 29 A}$; ${ }_{\text {phosS28 }}$ peptide and all other peptides used for ITC and the FP assay were synthesized by GenScript, Inc. 
Crystallization, data collection, structure determination, and model refinement

p $107 \Delta \mathrm{L}$ was prepared for crystallization by elution from a Superdex-75 (GE Healthcare) column in a buffer containing $25 \mathrm{mM}$ Tris, $500 \mathrm{mM} \mathrm{NaCl}$, and $5 \mathrm{mM}$ DTT (pH 8.0). LIN52 ${ }^{12-34 ; p h o s S 28}$ was added in threefold molar excess to $14 \mathrm{mg} / \mathrm{mL} \mathrm{p} 107 \Delta \mathrm{L}$, and $\mathrm{E}^{21-29}$ was added in twofold molar excess to $12 \mathrm{mg} / \mathrm{mL}$ p107 $\Delta \mathrm{L}$. After incubation for $30 \mathrm{~min}$ on ice, both complexes were crystallized by sitting-drop vapor diffusion at $4^{\circ} \mathrm{C}$. Plates formed after 2 wk in $100 \mathrm{mM}$ MES (pH 6.5), $1.6 \mathrm{M}\left(\mathrm{NH}_{4}\right)_{2} \mathrm{SO}_{4}$, and $4 \%$ PEG 400

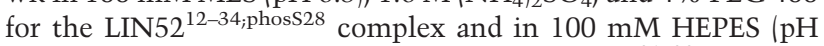
7.5), $1.7 \mathrm{M}\left(\mathrm{NH}_{4}\right)_{2} \mathrm{SO}_{4}$, and $4 \%$ PEG 400 for the $\mathrm{E}^{21-29}$ complex. Crystals were frozen in the proper well buffer with $20 \%$ ethylene glycol. Some crystals containing the LIN52 $2^{12-34 ; \text { phosS28 }}$ peptide were soaked with 20 -fold molar excess of the P29A mutant peptide before freezing.

Data were collected at the Advanced Photon Source, Argonne National Laboratory at Beamline 23-IDB. Diffraction spots were integrated using MOSFLM (Leslie 2006), and data were merged and scaled using Scala (Bailey 1994). Phases were first solved for the $\mathrm{E}^{21-29}$ complex by molecular replacement using Phaser (Mccoy et al. 2007). A homology model of p107 L L, which was constructed using the $\mathrm{Rb}$ pocket domain (PDB: 3POM), was used as a search model. p107 $\Delta$ L complexes with LIN52 peptides were then solved using the E7-p107 complex as a search model, as the crystal form was slightly different. Peptides were built with Coot (Emsley and Cowtan 2004), and the models were refined with PHENIX (Adams et al. 2010). Coordinates and structure factors have been deposited in PDB for the structures

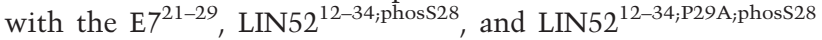
peptides under accession codes 4YOZ, 4YOS, and 4YOO, respectively.

\section{Coprecipitation assays}

For assays with recombinant protein, $50 \mu \mathrm{g}$ of each indicated protein was incubated with $15 \mu \mathrm{L}$ of either GS4B resin, Streptactin resin, or nickel sepharose Excel resin (all from GE Healthcare) in a buffer containing $25 \mathrm{mM}$ Tris, $150 \mathrm{mM} \mathrm{NaCl}$, and $1 \mathrm{mM}$ $\mathrm{DTT}$ ( $\mathrm{pH} 8.0$ ) for $30 \mathrm{~min}$ on ice. The resin was washed three times using the same buffer or with the addition of $20 \mathrm{mM}$ imidazole and was eluted using $30 \mu \mathrm{L}$ of elution buffer containing $25 \mathrm{mM}$ Tris, $200 \mathrm{mM} \mathrm{NaCl}$, and $1 \mathrm{mM}$ DTT $(\mathrm{pH}$ 8.0) with either 20 $\mathrm{mM}$ glutathione, $400 \mathrm{mM}$ imidazole, or $10 \mathrm{mM}$ desthiobiotin as needed. Under these conditions, we did not find that GST dimerization influences our results. For example, in Figure 4A GST-B-Myb ${ }^{654-700}$ only coprecipitates with other GST-tagged components of the MuvB core when LIN52 is present. Samples were analyzed by SDS-PAGE with Coomassie staining.

For assays in cells, stable cell lines were generated using a pMSCV-Flag-HA retroviral vector as described (Litovchick et al. 2007). Alternatively, cells were transiently transfected with pcDNA3.1 vectors encoding HA-tagged wild-type or mutant p130 alleles or pBabe vectors encoding SV40 large T antigen or adenovirus E1A. Mutant LIN52 and p130 alleles were obtained using site-directed mutagenesis (QuikChange, Agilent). T98G and BJ-hTERT cells were chosen for assaying DREAM assembly because they have intact $R b$ family genes and significant $G_{1}$ populations in asynchronously growing cells and arrest in $G_{0} / G_{1}$ readily (Litovchick et al. 2007). U2OS cells are highly proliferative and sensitive to overexpression of $\mathrm{Rb}$ family proteins; therefore, they were used for characterizing p130 phosphorylation site mutants as described (Farkas et al. 2002). Cells were extracted using EBC lysis buffer (50 mM Tris, $150 \mathrm{mM} \mathrm{NaCl}$, 0.5\% NP-40 at $\mathrm{pH}$ 7.4), immunoprecipitated, and subjected to Western blot anal- ysis as described previously (Litovchick et al. 2007). Band intensities were quantified using ImageJ software.

\section{Proliferation assay}

U2OS cells were seeded onto six-well plates at $2 \times 10^{5}$ cells per well and transfected with pcDNA3.1 vectors encoding p130 constructs and GFP. The p130 vector was transfected at a 4:1 molar ratio relative to the GFP vector. Forty-eight hours after transfection, cells were trypsinized and seeded in triplicate onto sixwell plates containing glass coverslips and allowed to attach for 24 h. Proliferating GFP-positive and GFP-negative cells were detected by indirect immunofluorescence staining using anti-Ki67 (Millipore) antibodies as described in Canhoto et al. (2000). To determine the fraction of proliferating cells in each sample, the number of Ki67-positive cells was determined in at least 100 cells per condition using an EVOS fluorescent microscope (AMG advanced microscope group) and a $20 \times$ objective. U2OS cells were chosen for this assay because they have intact $\mathrm{Rb}$ family members and are highly proliferative and thus sensitive to increases in the DREAM arrest activity.

\section{Calorimetry}

Equilibrium dissociation constants for p107, p130, Rb, LIN52, and E7 binding were obtained using ITC with the Micro Cal VP-ITC system (GE Healthcare). Peptides and proteins were dialyzed overnight and titrated into a buffer containing $25 \mathrm{mM}$ Tris, $200 \mathrm{mM} \mathrm{NaCl}$, and $5 \mathrm{mM} \mathrm{BME}(\mathrm{pH} 8.0)$ at $15^{\circ} \mathrm{C}$. Because of the difficulty in accurately determining peptide concentration, the peptide concentration was adjusted in the fitting such that all of the stoichiometry values were equal to 1.0.

\section{FP assay}

TMR-LIN52 ${ }^{12-34 ; p h o s S 28}$ was mixed at $20 \mathrm{nM}$ with p130 $\Delta$ L GSTp130 in a buffer containing $40 \mathrm{mM}$ Tris, $150 \mathrm{mM} \mathrm{NaCl}, 1 \mathrm{mM}$ DTT, and $0.1 \%$ Tween (pH 8.0). Twenty microliters of the reaction was used for the measurement in a 384-well plate. FP measurements were made in triplicate using a Perkin-Elmer EnVision plate reader, and reported FP values were determined using instrument software. Error bars in the plots show standard deviations for the three measurements of each point, while the reported errors in $K_{\mathrm{d}}$ and $K_{\mathrm{I}}$ are errors derived from curve fits. We note that absolute $K_{\mathrm{d}}$ measurements were typically tighter using the FP assay compared with ITC and suggest that this difference may be due to the presence of the dye in the peptide or other subtle differences in experimental conditions.

\section{Acknowledgments}

We thank Fred Dick for the DREAM-binding deficient p107 mutant plasmid. This work was supported by a grant from the National Institutes of Health (R01CA132685) to S.M.R.

\section{References}

Adams PD, Afonine PV, Bunkoczi G, Chen VB, Davis IW, Echols N, Headd JJ, Hung LW, Kapral GJ, Grosse-Kunstleve RW, et al. 2010. PHENIX: a comprehensive Python-based system for macromolecular structure solution. Acta Crystallogr D Biol Crystallogr 66: 213-221.

Andrejka L, Wen H, Ashton J, Grant M, Iori K, Wang A, Manak JR, Lipsick JS. 2011. Animal-specific C-terminal domain links 
myeloblastosis oncoprotein $(\mathrm{Myb})$ to an ancient repressor complex. Proc Natl Acad Sci 108: 17438-17443.

Bailey S. 1994. The Ccp4 suite-programs for protein crystallography. Acta Crystallogr D Biol Crystallogr 50: 760-763.

Balog ER, Burke JR, Hura GL, Rubin SM. 2011. Crystal structure of the unliganded retinoblastoma protein pocket domain. Proteins 79: 2010-2014.

Boichuk S, Parry JA, Makielski KR, Litovchick L, Baron JL, Zewe JP, Wozniak A, Mehalek KR, Korzeniewski N, Seneviratne DS, et al. 2013. The DREAM complex mediates GIST cell quiescence and is a novel therapeutic target to enhance imatinibinduced apoptosis. Cancer Res 73: 5120-5129.

Burke JR, Deshong AJ, Pelton JG, Rubin SM. 2010. Phosphorylation-induced conformational changes in the retinoblastoma protein inhibit E2F transactivation domain binding. I Biol Chem 285: 16286-16293.

Burke JR, Hura GL, Rubin SM. 2012. Structures of inactive retinoblastoma protein reveal multiple mechanisms for cell cycle control. Genes Dev 26: 1156-1166.

Canhoto AJ, Chestukhin A, Litovchick L, DeCaprio JA. 2000. Phosphorylation of the retinoblastoma-related protein p130 in growth-arrested cells. Oncogene 19: 5116-5122.

Cobrinik D. 2005. Pocket proteins and cell cycle control. Oncogene 24: 2796-2809.

Dannenberg JH, Schuijff L, Dekker M, van der Valk M, te Riele H. 2004. Tissue-specific tumor suppressor activity of retinoblastoma gene homologs p107 and p130. Genes Dev 18:2952-2962.

Dick FA, Rubin SM. 2013. Molecular mechanisms underlying RB protein function. Nat Rev Mol Cell Biol 14: 297-306.

Dowdy SF, Hinds PW, Louie K, Reed SI, Arnold A, Weinberg RA. 1993. Physical interaction of the retinoblastoma protein with human D cyclins. Cell 73: 499-511.

Emsley P, Cowtan K. 2004. Coot: model-building tools for molecular graphics. Acta Crystallogr D Biol Crystallogr 60: 2126-2132.

Farkas T, Hansen K, Holm K, Lukas J, Bartek J. 2002. Distinct phosphorylation events regulate p130- and p107-mediated repression of E2F-4. J Biol Chem 277: 26741-26752.

Fera D, Schultz DC, Hodawadekar S, Reichman M, Donover PS, Melvin J, Troutman S, Kissil JL, Huryn DM, Marmorstein R. 2012. Identification and characterization of small molecule antagonists of $\mathrm{pRb}$ inactivation by viral oncoproteins. Chem Biol 19: 518-528.

Forristal C, Henley SA, MacDonald JI, Bush JR, Ort C, Passos DT, Talluri S, Ishak CA, Thwaites MJ, Norley CJ, et al. 2014. Loss of the mammalian DREAM complex deregulates chondrocyte proliferation. Mol Cell Biol 34: 2221-2234.

Gagrica S, Hauser S, Kolfschoten I, Osterloh L, Agami R, Gaubatz S. 2004. Inhibition of oncogenic transformation by mammalian Lin-9, a pRB-associated protein. EMBO I 23: 4627-4638.

Gao J, Aksoy BA, Dogrusoz U, Dresdner G, Gross B, Sumer SO, Sun Y, Jacobsen A, Sinha R, Larsson E, et al. 2013. Integrative analysis of complex cancer genomics and clinical profiles using the cBioPortal. Sci Signal 6: pl1.

Georlette D, Ahn S, MacAlpine DM, Cheung E, Lewis PW, Beall EL, Bell SP, Speed T, Manak JR, Botchan MR. 2007. Genomic profiling and expression studies reveal both positive and negative activities for the Drosophila Myb MuvB/dREAM complex in proliferating cells. Genes Dev 21: 2880-2896.

Harrison MM, Ceol CJ, Lu X, Horvitz HR. 2006. Some C. elegans class B synthetic multivulva proteins encode a conserved LIN$35 \mathrm{Rb}$-containing complex distinct from a NuRD-like complex. Proc Natl Acad Sci 103: 16782-16787.
Henley SA, Dick FA. 2012. The retinoblastoma family of proteins and their regulatory functions in the mammalian cell division cycle. Cell Div 7: 10.

Jones RE, Wegrzyn RJ, Patrick DR, Balishin NL, Vuocolo GA, Riemen MW, Defeo-Jones D, Garsky VM, Heimbrook DC, Oliff A. 1990. Identification of HPV-16 E7 peptides that are potent antagonists of E7 binding to the retinoblastoma suppressor protein. J Biol Chem 265: 12782-12785.

Korenjak M, Taylor-Harding B, Binne UK, Satterlee JS, Stevaux O, Aasland R, White-Cooper H, Dyson N, Brehm A. 2004. Native E2F/RBF complexes contain Myb-interacting proteins and repress transcription of developmentally controlled E2F target genes. Cell 119: 181-193.

Lee JO, Russo AA, Pavletich NP. 1998. Structure of the retinoblastoma tumour-suppressor pocket domain bound to a peptide from HPV E7. Nature 391: 859-865.

Lee C, Chang JH, Lee HS, Cho Y. 2002. Structural basis for the recognition of the E2F transactivation domain by the retinoblastoma tumor suppressor. Genes Dev 16: 3199-3212.

Leslie AG. 2006. The integration of macromolecular diffraction data. Acta Crystallogr D Biol Crystallogr 62: 48-57.

Lewis PW, Beall EL, Fleischer TC, Georlette D, Link AJ, Botchan MR. 2004. Identification of a Drosophila Myb-E2F2/RBF transcriptional repressor complex. Genes Dev 18: 2929-2940.

Litovchick L, Sadasivam S, Florens L, Zhu X, Swanson SK, Velmurugan S, Chen R, Washburn MP, Liu XS, DeCaprio JA. 2007. Evolutionarily conserved multisubunit RBL2/p130 and E2F4 protein complex represses human cell cycle-dependent genes in quiescence. Mol Cell 26: 539-551.

Litovchick L, Florens LA, Swanson SK, Washburn MP, DeCaprio JA. 2011. DYRK1A protein kinase promotes quiescence and senescence through DREAM complex assembly. Genes Dev 25: 801-813.

Mccoy AJ, Grosse-Kunstleve RW, Adams PD, Winn MD, Storoni LC, Read RJ. 2007. Phaser crystallographic software. I Appl Crystallogr 40: 658-674.

Morris EJ, Dyson NJ. 2001. Retinoblastoma protein partners. AdV Cancer Res 82: 1-54.

Muller GA, Quaas M, Schumann M, Krause E, Padi M, Fischer M, Litovchick L, DeCaprio JA, Engeland K. 2012. The CHR promoter element controls cell cycle-dependent gene transcription and binds the DREAM and MMB complexes. Nucleic Acids Res 40: 1561-1578.

Nor Rashid N, Yusof R, Watson RJ. 2011. Disruption of repressive p130-DREAM complexes by human papillomavirus 16 E6/E7 oncoproteins is required for cell-cycle progression in cervical cancer cells. J Gen Virol 92: 2620-2627.

Obenauer JC, Cantley LC, Yaffe MB. 2003. Scansite 2.0: proteome-wide prediction of cell signaling interactions using short sequence motifs. Nucleic Acids Res 31: 3635-3641.

Pilkinton M, Sandoval R, Colamonici OR. 2007. Mammalian Mip/LIN-9 interacts with either the p107, p130/E2F4 repressor complex or B-Myb in a cell cycle-phase-dependent context distinct from the Drosophila dREAM complex. Oncogene 26: 7535-7543.

Reichert N, Wurster S, Ulrich T, Schmitt K, Hauser S, Probst L, Gotz R, Ceteci F, Moll R, Rapp U, et al. 2010. Lin9, a subunit of the mammalian DREAM complex, is essential for embryonic development, for survival of adult mice, and for tumor suppression. Mol Cell Biol 30: 2896-2908.

Rubin SM. 2013. Deciphering the retinoblastoma protein phosphorylation code. Trends Biochem Sci 38: 12-19.

Rubin SM, Gall AL, Zheng N, Pavletich NP. 2005. Structure of the $\mathrm{Rb}$ C-terminal domain bound to E2F1-DP1: a mechanism for phosphorylation-induced E2F release. Cell 123: 1093-1106. 
Guiley et al.

Sadasivam S, DeCaprio JA. 2013. The DREAM complex: master coordinator of cell cycle-dependent gene expression. Nat Rev Cancer 13: 585-595.

Sadasivam S, Duan S, DeCaprio JA. 2012. The MuvB complex sequentially recruits B-Myb and FoxM1 to promote mitotic gene expression. Genes Dev 26: 474-489.

Schmit F, Korenjak M, Mannefeld M, Schmitt K, Franke C, von Eyss B, Gagrica S, Hanel F, Brehm A, Gaubatz S. 2007. LINC, a human complex that is related to pRB-containing complexes in invertebrates regulates the expression of G2/M genes. Cell Cycle 6: 1903-1913.

Singh M, Krajewski M, Mikolajka A, Holak TA. 2005. Molecular determinants for the complex formation between the retinoblastoma protein and LXCXE sequences. I Biol Chem 280: 37868-37876.

Smith EJ, Leone G, DeGregori J, Jakoi L, Nevins JR. 1996. The accumulation of an E2F-p130 transcriptional repressor distin- guishes a G0 cell state from a G1 cell state. Mol Cell Biol 16: 6965-6976.

Ubersax JA, Ferrell JE Jr. 2007. Mechanisms of specificity in protein phosphorylation. Nat Rev Mol Cell Biol 8: 530-541.

van den Heuvel S, Dyson NJ. 2008. Conserved functions of the pRB and E2F families. Nat Rev Mol Cell Biol 9: 713-724.

Wen H, Andrejka L, Ashton J, Karess R, Lipsick JS. 2008. Epigenetic regulation of gene expression by Drosophila Myb and E2F2-RBF via the Myb-MuvB/dREAM complex. Genes Dev 22: 601-614.

Wirt SE, Sage J. 2010. p107 in the public eye: an Rb understudy and more. Cell Div 5: 9.

Xiao B, Spencer J, Clements A, Ali-Khan N, Mittnacht S, Broceno C, Burghammer M, Perrakis A, Marmorstein R, Gamblin SJ. 2003. Crystal structure of the retinoblastoma tumor suppressor protein bound to E2F and the molecular basis of its regulation. Proc Natl Acad Sci 100: 2363-2368. 


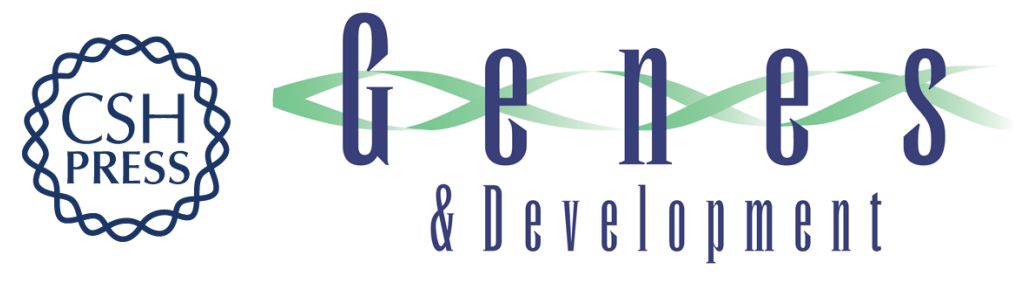

\title{
Structural mechanisms of DREAM complex assembly and regulation
}

\author{
Keelan Z. Guiley, Tyler J. Liban, Jessica G. Felthousen, et al.
}

Genes Dev. 2015, 29: originally published online April 27, 2015

Access the most recent version at doi:10.1101/gad.257568.114

\section{Supplemental Material \\ http://genesdev.cshlp.org/content/suppl/2015/04/23/gad.257568.114.DC1 \\ References \\ This article cites 48 articles, 19 of which can be accessed free at: http://genesdev.cshlp.org/content/29/9/961.full.html\#ref-list-1}

Creative Commons License

Email Alerting
Service
This article is distributed exclusively by Cold Spring Harbor Laboratory Press for the first six months after the full-issue publication date (see

http://genesdev.cshlp.org/site/misc/terms.xhtml). After six months, it is available under a Creative Commons License (Attribution-NonCommercial 4.0 International), as described at http://creativecommons.org/licenses/by-nc/4.0/.

Receive free email alerts when new articles cite this article - sign up in the box at the top right corner of the article or click here.

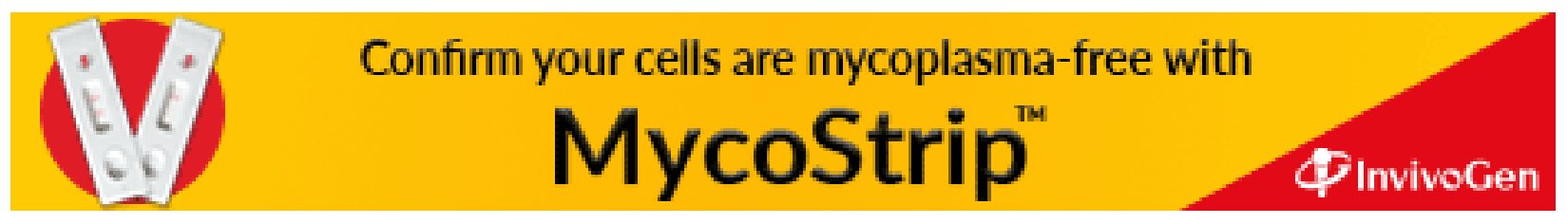

